\title{
Chapter 17 \\ Deterrence in Peace Operations: Look Beyond the Battlefield and Expand the Number of Targets and Influence Mechanisms
}

\author{
Peter Viggo Jakobsen
}

\section{Contents}

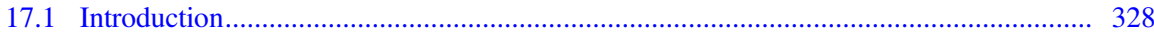

17.2 Rational Deterrence in Peace Operations - The Predominant View .......................... 330

17.3 Increasing the Number of Actors to Deter ......................................................... 332

17.4 Increasing the Number of Influence Mechanisms .................................................... 335

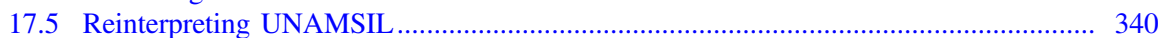

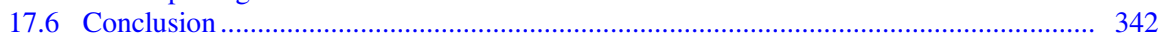

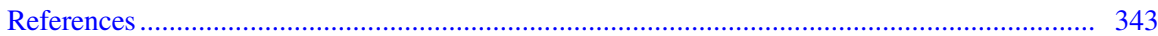

\begin{abstract}
The peace operations literature suffers from a narrow focus on battlefield deterrence. It ignores the need to deter actors beyond the battlefield from supporting the combatants using force, and analyses the use of military threats and force in peace operations in a vacuum without taking into account the other instruments that deterring actors employ simultaneously to influence the combatants, combatant allies, combatant supporters and bystanders that undermine deterrence in peace operations. Since most peace operation forces lack the capacity and willingness to threaten and use force in accordance with the requirements stipulated by rational deterrence theory, influencing actors beyond the battlefield is more important with respect to deterring violence than the military efforts undertaken by peace operation forces to deter combatants from using force or to compel them to stop doing so. Accordingly, this chapter develops a new analytical framework that will enable peace operation theorists and practitioners to target all the actors that undermine deterrence on the battlefield and beyond with all the tools at their disposal-
\end{abstract}

P. V. Jakobsen $(\bowtie)$

The Institute for Strategy, The Royal Danish Defence College, Copenhagen, Denmark

e-mail: peja@fak.dk

P. V. Jakobsen

Center for War Studies, University of Southern Denmark, Odense, Denmark

(C) The Author(s) 2021

F. Osinga and T. Sweijs (eds.), NL ARMS Netherlands Annual Review

of Military Studies 2020, NL ARMS, https://doi.org/10.1007/978-94-6265-419-8_17 
persuasion, inducement and coercion. The framework will improve both theory and practice by providing a better understanding of the conditions under which peace operations can contribute to deterring and, if need be, compelling combatants from using force as well as identifying the tools that practitioners can employ to this end. It highlights that peace operations merely constitute the top of the deterrence iceberg, and that peace operation forces must be supported by other actors and tools to succeed with respect to deterring violence and facilitating conflict resolution.

Keywords coercion $\cdot$ deterrence $\cdot$ norms $\cdot$ peacekeeping $\cdot$ peace enforcement • persuasion $\cdot$ promises $\cdot$ punishment $\cdot$ rewards and threats

\subsection{Introduction}

The deterrence literature has developed through four waves, and, as stated by Osinga and Sweijs in the preface of this volume, the ambition in this book is to start a fifth by using new and emerging insights to address the challenges created by the growing rivalry among China, Russia and the United States, the changing character of war and rapid technological change. ${ }^{1}$ The focus in this chapter is the nexus between deterrence theory and peace operations. The main challenge in the field of peace operations is to bring the understanding and practice of deterrence up to speed with the understanding and practice employed in most other fields. The peace operations literature is stuck in the second wave of deterrence theory that led to the formulation of the so-called rational theory of deterrence during the Cold War. According to this theory, deterrence is a rational strategy based on cost-benefit calculations, and the key to success is to communicate a clear threat to use force against potential attackers in a way that makes the cost of aggression exceed any conceivable gain. ${ }^{2}$ Peace operation scholars and practitioners have used the rational theory of deterrence to identify the requirements for military deterrence at the tactical level, and to highlight the inability of many United Nations (UN) peace operation contingents to meet them. ${ }^{3}$ This understanding has resulted in a trench war between two schools of thought. ${ }^{4}$ In one trench, you have the "robust peacekeepers" advocating that peace operation forces be equipped and mandated to threaten and use force beyond self-defence to deter aggression and protect

\footnotetext{
${ }^{1}$ See the Preface by Osinga and Sweijs in the present volume; Jervis 1979; Knopf 2010; Lupovici 2010.

${ }^{2}$ See the symposium on rational deterrence theory in World Politics 41, no. 2 (January 1989), pp. 143-237.

${ }^{3}$ Berdal 2019; Crawford 1998.

${ }^{4}$ For reviews of this debate see Findlay 2003; Jakobsen 2000a.
} 
civilians. ${ }^{5}$ In the other trench, you have the "peacekeeping traditionalists" arguing that this will never work, because (UN) peace forces rarely have the military capacity and the willingness required for deterrence success in situations where consent from the conflicting parties is limited or non-existent. ${ }^{6}$

Attempts to authorize peace forces to use force beyond self-defence to deter violence have not been particularly successful, and the increasing number of aid workers and UN peacekeepers killed in recent years indicates the need for a new approach (see Table 17.1). Going back to traditional peacekeeping as advocated by the peacekeeping traditionalists is not a solution in itself, however, as there is far more to deterrence than the deployment of peacekeeping forces as this chapter will show.

I draw on two findings from the third and fourth waves of deterrence theory to propose a better solution. I conceptualize aggressors as coalitions composed of combatants, combatant allies, combatant supporters and bystanders, and incorporate military deterrence into a broader influence strategy that also involves persuasion and inducement. The resulting framework has three advantages compared to the predominant understanding of deterrence in the peace operations literature. First, it increases the number of deterrence targets. Second, it highlights that deterring actors have more influence mechanisms than military threats and use of force. Third, it shows that a peace operations force merely constitutes the top of the deterrence/influence iceberg. Other factors may make its (lack of) military capacity irrelevant for deterrence or rather influence success.

My argument has five parts. The first presents the predominant understanding of deterrence in peace operations theory and practice. The second develops a new typology of actors causing deterrence failure in peace operations. The third part shows how peace forces and other deterring actors use persuasion and inducement as well as coercion to increase the prospects of deterrence success. The fourth illustrates the advantages of the framework in a case study of the UN operation in Sierra Leone (UNAMSIL). UNAMSIL is a paradigmatic case for the robust peacekeeping school, and I use it to demonstrate that there was far more to its success than the deployment of a peacekeeping force capable and willing to use force at the tactical level. The chapter ends with a conclusion summarizing the main points and their implications for peace operations theory and practice.

\footnotetext{
${ }^{5}$ Nsia-Pepra 2017; Cruz et al. 2017.

${ }^{6}$ Berdal, op cit; Karlsrud 2015.
} 
Table 17.1 Aid worker and UN peacekeeping (PKO) fatalities 1997-2017

\begin{tabular}{l|l|l|l|c|c|l|l|l|l|l|l}
\hline & 1997 & 1999 & 2001 & 2003 & 2005 & 2007 & 2009 & 2011 & 2013 & 2015 & 2017 \\
\hline $\begin{array}{l}\text { Aid } \\
\text { workers }\end{array}$ & 39 & 33 & 27 & 87 & 53 & 88 & 109 & 86 & 156 & 110 & 139 \\
\hline UN PKO & 49 & 39 & 72 & 108 & 131 & 90 & 121 & 115 & 110 & 125 & 138 \\
\hline
\end{tabular}

(Source Aid Worker Security Database and United Nations Operations and Crisis Centre)

\subsection{Rational Deterrence in Peace Operations-The Predominant View}

The peace operation literature conceptualizes deterrence as the use of military threats to deter armed actors from attacking others in the mission area. The key to success is to deploy a peace force capable of using force against any attacker in a way that makes the costs of aggression exceed any conceivable gain. The peace force must threaten to use its military capacity against any potential attacker in a clear and credible manner for deterrence to succeed.

If follows from this understanding that unarmed observer forces and lightly armed peacekeeping forces have no or very limited military deterrence capacity (see Table 17.2). As Alan James has put it in a seminal work, "peacekeepers are not in the business of threatening and using force". 7 Their presence may have a deterrent effect if potential attackers believe that attacks on the peace force will trigger retaliation from other actors that outweigh the benefits, but the force itself has little military deterrent effect and depends upon consent and cooperation from the parties to the conflict for its success. Robust peacekeeping forces and peace enforcement forces have more military deterrence capacity as well as a mandate to use force beyond self-defence (see Table 17.2). This gives them a military capacity to deter attacks at the tactical and strategic levels respectively, if they have the capability to do so and issue credible threats of force to punish non-compliance or deny potential attackers their objectives.

In this perspective, deterrence is a question of military capacity and a willingness to issue and execute threats of force that will make the cost of aggression exceed any gain. Deterrence success is a function of effective command and control, equipment, force numbers, training, mandates, credibility and threats. If deterrence fails, unarmed observers and peacekeepers have no option but to withdraw or call upon others to intervene militarily. This is the option advocated by peacekeeping traditionalists. To prevent deterrence failure and withdrawals, the robust peacekeeping school advocates the deployment of peace forces mandated, capable and willing to use force beyond self-defence to deter aggression. Yet this option rarely exists as very few peace forces meet these military requirements for deterrence success.

\footnotetext{
${ }^{7}$ James 1990, p. 2.
} 
Table 17.2 Peace operation forces, warfighting forces and military deterrence

\begin{tabular}{|c|c|c|c|c|}
\hline Force type & $\begin{array}{l}\text { Composition and } \\
\text { tasks }\end{array}$ & Consent & Use of force & $\begin{array}{l}\text { Deterrence } \\
\text { capacity }\end{array}$ \\
\hline $\begin{array}{l}\text { Observer } \\
\text { force }\end{array}$ & $\begin{array}{l}\text { - Unarmed } \\
\text { military } \\
\text { observers tasked } \\
\text { to monitor } \\
\text { compliance }\end{array}$ & $\begin{array}{l}\text { - Consent and } \\
\text { cooperation } \\
\text { from the parties } \\
\text { to the conflict } \\
\text { necessary for } \\
\text { success }\end{array}$ & - None & $\begin{array}{l}\text { - No military } \\
\text { deterrence } \\
\text { capacity }\end{array}$ \\
\hline $\begin{array}{l}\text { Peacekeeping } \\
\text { force }\end{array}$ & $\begin{array}{l}\text { - Lightly armed } \\
\text { units in } \\
\text { soft-skinned } \\
\text { vehicles tasked } \\
\text { to monitor } \\
\text { compliance }\end{array}$ & $\begin{array}{l}\text { - Consent and } \\
\text { cooperation } \\
\text { from the parties } \\
\text { to the conflict } \\
\text { necessary for } \\
\text { success }\end{array}$ & $\begin{array}{l}\text { - Minimum } \\
\text { use of force } \\
\text { in } \\
\text { self-defence } \\
\text { only at the } \\
\text { tactical level }\end{array}$ & $\begin{array}{l}\text { - Limited } \\
\text { military } \\
\text { deterrence } \\
\text { capacity }\end{array}$ \\
\hline $\begin{array}{l}\text { Robust } \\
\text { peacekeeping } \\
\text { force }\end{array}$ & $\begin{array}{l}\text { - Armed military } \\
\text { units tasked to } \\
\text { monitor and } \\
\text { enforce } \\
\text { compliance at } \\
\text { the tactical level }\end{array}$ & $\begin{array}{l}\text { - Consent and } \\
\text { cooperation } \\
\text { from the parties } \\
\text { to the conflict at } \\
\text { the strategic } \\
\text { level necessary } \\
\text { for success }\end{array}$ & $\begin{array}{l}\text { - Use of force } \\
\text { in } \\
\text { self-defence } \\
\text { and to } \\
\text { enforce } \\
\text { compliance } \\
\text { at the tactical } \\
\text { level }\end{array}$ & $\begin{array}{l}\text { - Military } \\
\text { deterrence } \\
\text { capacity at the } \\
\text { tactical level }\end{array}$ \\
\hline $\begin{array}{l}\text { Peace } \\
\text { Enforcement } \\
\text { force }\end{array}$ & $\begin{array}{l}\text { - Combat capable } \\
\text { military force } \\
\text { tasked to } \\
\text { monitor and } \\
\text { enforce } \\
\text { compliance }\end{array}$ & $\begin{array}{l}\text { - Some consent } \\
\text { and cooperation } \\
\text { from the parties } \\
\text { necessary for } \\
\text { success }\end{array}$ & $\begin{array}{l}\text { - Use of force } \\
\text { in } \\
\text { self-defence } \\
\text { and to } \\
\text { enforce } \\
\text { compliance } \\
\text { at the } \\
\text { strategic } \\
\text { level }\end{array}$ & $\begin{array}{l}\text { - Military } \\
\text { deterrence } \\
\text { capacity at the } \\
\text { strategic level }\end{array}$ \\
\hline $\begin{array}{l}\text { Warfighting } \\
\text { force }\end{array}$ & $\begin{array}{l}\text { - Combat capable } \\
\text { military force } \\
\text { tasked to defeat } \\
\text { designated } \\
\text { enemies and } \\
\text { impose } \\
\text { compliance } \\
\text { upon them }\end{array}$ & $\begin{array}{l}\text { - No consent and } \\
\text { cooperation } \\
\text { required for } \\
\text { success }\end{array}$ & $\begin{array}{l}\text { - Use of force } \\
\text { to defeat all } \\
\text { armed } \\
\text { opposition }\end{array}$ & $\begin{array}{l}\text { - Not applicable } \\
\text { as the purpose } \\
\text { is to win a war; } \\
\text { not to use } \\
\text { threats to } \\
\text { prevent or stop } \\
\text { one }\end{array}$ \\
\hline
\end{tabular}

(Source The author)

The predominant understanding of deterrence provides poor explanations of peace operation outcomes. Unarmed military observers and peacekeeping forces lacking the capability and willingness to threaten and use force in a credible manner have contributed to deterrence and mission success in several peace operations, whereas highly capable forces have failed to do so. The failure of NATOs peace 
enforcement mission in Afghanistan clearly demonstrates that there is more to peace operations success than military deterrence at the tactical and strategic levels. ${ }^{8}$

This lack of explanatory power makes it necessary to rethink the understanding of deterrence in the peace operations literature. Two contributions made in the third and fourth waves of deterrence theory are useful to this end. The first is the move away from analysing deterrence as battlefield interaction between unitary (state) actors. The problems experienced by peacekeeping forces in the 1990s and the September 112001 terrorist attacks have led deterrence scholars to conceptualize deterring actors and aggressors as coalitions and networks. The second contribution is the move to view deterrence as part of a broader influence strategy, which integrates threats, persuasion and positive inducements into a coherent strategy. The next sections briefly present these contributions and demonstrate their relevance and implications for peace operations theory and practice.

\subsection{Increasing the Number of Actors to Deter}

The repeated attacks on the United Nations Protection Force (UNPROFOR) in Bosnia (1992-1995) induced scholars to examine how peace forces could use military threats and limited force to deter attacks from occurring in the first place, and to coerce aggressors to stop their use of force when deterrence broke down. Drawing on the works of second-generation deterrence (and compellence) theorists, I developed a parsimonious ideal policy framework identifying the minimum conditions for success that a strategy must meet to maximise the prospects of deterring or compelling combatants from attacking each other, civilians or the peace force. Compellence involves threats and, if need be, use of limited force to coerce an actor to do something against its will, i.e., stop an ongoing attack or give up something of value such as territory. Peace forces deployed in a context of ongoing conflict usually attempt to deter and compel at the same time, and the distinction between the two types of threat can be fluid and situational in this environment. Peace forces may often need to threaten and use force in order to stop attacks and re-establish deterrence, and this makes the ideal policy framework useful as it covers both types of threat.

The ideal policy is composed of a (1) a threat of force to defeat the opponent or deny it its objectives quickly with little cost; (2) a deadline for compliance; (3) an assurance to the adversary that compliance will not lead to more demands; and finally (4) an offer of carrots or positive inducements for compliance. To make a threat so potent and credible that the costs of non-compliance become unbearable,

\footnotetext{
${ }^{8}$ NATO forces were configured and mandated to carry out peace enforcement when they deployed in 2003. However, the unexpected level and ferocity of Taliban resistance forced it to change its posture and engage in counterinsurgency and warfighting instead.
} 
the coercer should ideally have the capability to defeat the adversary quickly with little cost. The logic here is that that a threat to fight a short victorious war is inherently more credible than a threat to fight a long and bloody one. A deadline for compliance is key when the coercer is trying to stop attacks and other forms of hostile behaviour already taking place. It helps to create the sense of urgency and fear of unacceptable escalation in the mind of the adversary that is required for success. Moreover, unwillingness to issue a deadline is likely to be regarded as a sign of weakness and a lack of resolve by the adversary, who will be under pressure and prone to misperception and wishful thinking. Deadlines serve to limit the scope for such mistakes as well as counter-coercion and salami tactics aimed at undermining the willingness of the coercer to execute its threat. Assurance against future threats, the third component, serves to convince the adversary that compliance will not trigger tougher demands. This is crucial, as the adversary will have little incentive to comply if it fears this to be the case. Finally, use of inducements is included to reduce the costs of compliance for the adversary and increase the benefits of refraining from or stopping the use of force. ${ }^{9}$

My case study of UNPROFOR highlighted the difficulties involved when a coalition of actors has to formulate and implement a coercive strategy meeting the requirements of the ideal policy. Disagreements among the troop contributing nations, UN and NATO representatives and the permanent members of the UN Security Council often undermined threat credibility. The difficulties of meeting the ideal policy requirements were compounded by the fact that the coercing actors had to coerce several actors simultaneously. In addition to the main combatants made up by Bosnian Croat, Bosniak and Bosnian Serb forces, the UN and NATO also had to coerce Serbia to stop its support for the Bosnian Serbs. The use of economic sanctions played a key role in coercing Serbian President Milosevic to pressure the Bosnian Serbs to cease fire and accept the Dayton Peace Accords, which ended the war in Bosnia in 1995. ${ }^{10}$

The Bosnian conflict highlighted a need to move beyond the rational unitary assumption that second wave deterrence and compellence theory rests on. The conflict pitted coalitions against each other, and this created a need to deter and, if need be, coerce a variety actors on and beyond the battlefield simultaneously. It was not sufficient for deterrence success to threaten the use of force against the combatants. It was also necessary to threaten actors supporting aggression at the regional and global levels. Deterrence had to be tailor-made at each level to target the relevant actors, and threat credibility had to be established and maintained from the UN Security Council to the battlefield. Coalitional cohesion emerged as an important requirement of success. ${ }^{11}$

The September 112001 terrorist attacks reinforced the need for multi-level and multi-actor deterrence. The need to deter terrorist attacks posed a seemingly

\footnotetext{
${ }^{9}$ Jakobsen 1998, pp. 25-34; Jakobsen 2000b.

${ }^{10}$ Jakobsen 1998, op. cit.

${ }^{11}$ Jakobsen, op. cit.
} 
unsurmountable problem: how do you deter highly committed terrorists willing to die for their cause? The solution provided by deterrence theorists was to disaggregate terrorist organisations into their component parts such as operatives carrying out attacks, financiers, logisticians, recruiters, supporting population segments, state supporters and religious/ideological leaders. ${ }^{12}$ This made it possible to target each component with tailor-made campaigns to influence them to refrain from or cease their support for terrorist activities.

The key take-away from these efforts to rethink deterrence theory and practice to meet the challenges posed by internationalized intra-state conflicts and transnational terrorist networks is the need to target all the actors contributing to deterrence failure at the local, regional and global levels simultaneously. It is not sufficient to focus on tactical and operational (mission area) deterrence as most of the peace operation literature currently does. It is also necessary to target the actors beyond the battlefield that enable combatants to use force against peace forces, civilians and other parties to the conflict. The actors that make or break deterrence in peace operations can be categorized in four groups:

(1) Combatants that use force on the battlefield in mission areas in ways that cause deterrence to fail;

(2) Combatant allies that provide direct material support (men, materiel and money) to combatants using force;

(3) Combatant supporters that prevent others from taking action to stop deterrence failure by blocking action in regional or global institutions; and finally

(4) Bystanders that fail to use their power to reduce or stop deterrence failure at all levels from the battlefield to the global level.

The African Union-United Nations Hybrid Operation in Darfur (UNAMID) deployed in 2007, which by mid 2020 had suffered 278 fatalities, ${ }^{13}$ illustrates the utility of the typology. The case is useful because it is very easy to identify actors contributing to deterrence failure in each of the four categories. The Sudanese government was the principal combatant causing deterring failure in the mission areas using militias to attack civilians, humanitarian organisations and UNAMID forces. ${ }^{14}$ China's was Sudan's key combatant ally providing it with material (economic and military) support. ${ }^{15}$ China, assisted by Russia, also acted as a combatant supporter by opposing UN resolutions threatening use of force and sanctions, and by insisting that UN peacekeepers deploy with the consent of the Sudanese government. This made it difficult for the UN Security Council to punish the Sudanese government for undermining deterrence. Finally, the Western great powers in the Security Council acted as bystanders because they refused to provide

\footnotetext{
${ }^{12}$ Knopf 2010, p. 10; Lupovici 2010; Wilner 2011.

${ }^{13}$ As of 3 August 2020. https://peacekeeping.un.org/en/mission/unamid.

${ }^{14}$ Lynch 2014a.

${ }^{15}$ Shinn 2009.
} 
troops and aircraft for UNAMID and did little to influence the Sudanese government, China and Russia to prevent, stop and reduce the violence. ${ }^{16}$

The UNAMID case highlights the need to go beyond the mission area in order to identify all the actors influencing deterrence outcomes. To increase the prospects of deterrence success, all actors on the battlefield and beyond with a motivation and a capacity to undermine deterrence need to be influenced to refrain from doing so. Successful deterrence in peace operations require cooperation and support from key actors at all levels simultaneously, and anyone contemplating the deployment of peace forces need to assess the likelihood of obtaining the necessary cooperation at all these levels, regardless of the type of operation envisaged. Successful deterrence in peace operations is a team effort requiring cooperation and coordination from the local to the global level. Yet identifying whom to influence is only half the battle. The next step is to identify which influence mechanisms to use. This is the topic of the next section.

\subsection{Increasing the Number of Influence Mechanisms}

In addition to the need for adopting a multi-actor and multi-level perspective, my ideal policy analysis of UNPROFOR also showed that the prospects for deterrence and compellence success increased when deterring actors coupled threats with persuasion and positive inducements. ${ }^{17}$ Other third and fourth wave studies show similar results suggesting the need for integrating deterrent threats into broader influence strategies that use threats to increase the costs of attacks as well as rewards to increase the benefits of restraint (not attacking) simultaneously. ${ }^{18}$

This adds two additional influence mechanisms - persuasion and inducementto the quiver of deterring actors. This insight has found its way into the peace operations literature. Lise Morjé Howard captures all three mechanisms in her recent study of peacekeeping power. However, she regards them as alternatives and ends up making the peacekeeping traditionalist argument that coercion is not an option for (UN) peacekeepers. ${ }^{19}$ She consequently fails to consider how peace forces and other actors in mission areas can use all three mechanisms simultaneously to increase their leverage vis-à-vis potential attackers. Since Howard's study focuses on the activities undertaken by UN peacekeeping operations in the field, she

\footnotetext{
${ }^{16}$ Lynch 2014b.

${ }^{17}$ Jakobsen 1998, op. cit.; Jakobsen 2000b, op. cit.

${ }^{18}$ George 2003, p. 465; George and Smoke 1974, p. 606; Stein 1991; United States Department of Defense 2006, p. 5; Wilner op. cit., pp. 7-8. For a classic first generation study also suggesting the use of promises to influence costs and benefits simultaneously see Snyder 1961, pp. 9-10.

${ }^{19}$ Howard 2019.
} 
also ignores the leverage that these mechanisms can provide beyond the battlefield vis-à-vis combatant allies, combatant supporters and bystanders. The section below briefly presents the three mechanisms and their operational activities in turn.

Persuasion involves the transmission of information and knowledge to persuade (potential) attackers to refrain from using force. Such persuasion can be linked to peace processes and negotiations addressing the underlying drivers of conflict, or to common or local cultural understandings and norms making the resort to force illegitimate or counterproductive. As pointed out by fourth wave deterrence theorists, norms and taboos can increase the prospects of deterrence success by increasing the reputational costs of using force. ${ }^{20}$ The norms of deterrence, non-proliferation, and non-use have in this way contributed to the success of nuclear deterrence. ${ }^{21}$ In the same way, deterring actors can use global and local cultural norms and taboos as part of their efforts to persuade combatants, combatant allies, combatant supporters and bystanders to refrain from (contributing to) the use of force. ${ }^{22}$ Persuasion seeking to deter aggression takes two forms: general and immediate. General persuasion is undertaken in peacetime to prevent violence from breaking out in the first place. Immediate persuasion is undertaken during crises or war to stop the outbreak of violence or to reduce or stop ongoing violence.

General persuasion improves the prospects of deterrence success by building support for and internalizing norms that make the resort to force illegitimate. Examples of such efforts include information campaigns, educational programs, and advocacy campaigns seeking to increase the knowledge and respect for international humanitarian law (IHL), prohibit sexual violence against women, terrorism, violence against non-combatants, use of child soldiers, use of "barbaric" weapons such as landmines, chemical weapons, nuclear weapons, "killer" drones and so on. The UN, the International Committee of the Red Cross (ICRC) and many humanitarian organisations carry out such activities targeting states, schoolchildren, university students, the public, the mass media and Armed Non-State Actors (ANSAs).

Immediate persuasion seeks to convince identified (potential) combatants in mission areas to refrain from or to cease use of force. The UN, the ICRC and Non-Governmental Actors (NGOs) operating in conflict zones do this by engaging directly with actors that threaten to or undermine deterrence, and by providing information about ongoing conflicts to other actors with a capacity to influence them: local community leaders, the media, other organisations and states. These organisations have developed handbooks and humanitarian negotiation tools to help their personnel create and preserve consent and cooperation from combatants at the tactical level. ${ }^{23}$

\footnotetext{
${ }^{20}$ Lupovici 2010; Nye 2016/17, pp. 60-63; Wilner 2011.

${ }^{21}$ Freedman 2013; Tannenwald 2007.

${ }^{22}$ Schirch 2006.

${ }^{23}$ ICRC 2015; Bessler 2006.
} 
When general and immediate persuasion proves insufficient with respect to preventing and stopping military aggression, deterring actors can resort to inducement, which backs persuasion with positive inducements in the form of promises and rewards. The rewards can be non-tangible in the form of recognition and legitimacy and tangible in the form of resources and services or silence in the face of human suffering or violations of IHL.

With respect to recognition and legitimacy, the mere act of negotiation and cooperation with a peace force or an international mediator may serve as a positive incentive bestowing legitimacy on an armed group. ANSAs with political aspirations often use cooperation with international actors to demonstrate their legitimacy and ability to govern areas under their control. ${ }^{24}$ The importance attributed to such legitimacy is not only visible in way that ANSAs use it strategically. It is also visible in the way governments fighting ANSAs attempt to deny them legitimacy by banning contacts between ANSAs and the UN and other international organisations, and by designating ANSAs as terrorists. ${ }^{25}$

The resources and services that peace forces and humanitarian organisations command constitute another important source of leverage that can be used as positive incentives in bargaining situations. Peace forces and humanitarian organisations bring food, water, medical services, and employment opportunities; they rent offices, housing and cars and help grow the local economy. ${ }^{26}$

A third positive incentive commanded by peace forces and humanitarian organisations is (a promise to maintain) silence in the face of humanitarian suffering or atrocities/war crimes. This is an asset that UN peace forces, ICRC and Médecins Sans Frontières (MSF) have used over the years in their dealings with governments and non-state actors to gain and preserve humanitarian access. ${ }^{27}$ It has gained in importance as aggressors have come to fear public denouncements. For instance, al-Shabaab will only grant access to areas under its control to humanitarian organisations that promise not to speak out publicly against the group. ${ }^{28}$ (Promise of) silence has clear and obvious limits as it may facilitate continued aggression in some circumstances. Nevertheless, it does provide leverage that can be used to influence aggressors (combatants, allies and supporters) fearing external intervention to take steps to reduce or stop the use of violence on the battlefield.

When peace forces and humanitarian organisations break their silence and name and shame identified aggressors, they cross the threshold from inducement to $\mathrm{co}$ ercion. This mechanism relies on threats and punishments short of full-scale force in order to influence actors to refrain from or stop using force. It consequently incorporates both deterrence and compellence, in addition to the use of military threats and limited force that dominates the rational deterrence debate in the peace

\footnotetext{
${ }^{24}$ Loeb 2013, p. 16.

${ }^{25}$ Grace 2015; Jackson 2012.

${ }^{26}$ Abild 2009, p. 14.

${ }^{27}$ Kellenberger 2004; Magone et al. 2011, pp. 6, 46, 92, 110, 120.

${ }^{28}$ Jackson and Aynte 2013, p. 10.
} 
operation literature. Deterring actors have three additional coercive instruments at their disposal: naming and shaming, suspension/termination of peace operations and political and economic sanctions.

Naming and shaming become coercion when the identification of actors responsible for undermining deterrence is accompanied with calls for or threats of punitive action (political, economic and military) to stop them. Humanitarian organisations instruct their personnel to use naming and shaming actively to mobilize local populations, the media and international public opinion to pressure combatant allies, combatant supporters and bystanders to take punitive action to stop combatants using force. ${ }^{29}$

(Threats of) suspension or termination of humanitarian relief and peace operations are used frequently against combatants, but it has also been employed against bystanders using humanitarian assistance as an alibi for inaction to coerce them to act. In 1992, a threat to withdraw from Somalia made by a group of American NGOs helped to coerce the United States to launch a military intervention into Somalia (Operation Restore Hope) to create a secure environment for humanitarian operations. $^{30}$

(Threats of) diplomatic and economic sanctions are frequently used in support of peace forces to deter aggression or more frequently to compel combatants, combatant allies and supporters to take action to stop attacks already occurring. Diplomatic sanctions involve restriction of diplomatic representation and interaction, suspension of organisational memberships, cultural and sport bans and the establishment of war crimes tribunals. Economic sanctions cover a wide array of instruments such as arms embargoes, asset freezes, commodity bans (for instance, charcoal, diamonds, oil and timber), financial restrictions and travel bans. The UN relied on both types of sanctions in its attempts to compel primarily the Former Republic of Yugoslavia/Serbia-Montenegro to end its material support for the Bosnian Serb forces during the war in Bosnia 1992-95 and deter escalation. ${ }^{31}$ Since then, the use of UN sanctions has grown significantly, ${ }^{32}$ in 2015 a major study found that $59 \%$ of UN sanctions were used together with peace forces to manage armed conflicts. $^{33}$

All the mechanisms and means depicted in Table 17.3 contribute to deterrence in peace operations, and most of them are employed simultaneously from the local to the global levels by NGOs, peace forces, international organisations and states to influence the coalition of actors (combatants, combatant allies, combatant supporters and bystanders) that undermines deterrence in a specific conflict. Table 17.3 illustrates that the existing peace operation literature focussing on the requirements of military battlefield deterrence misses most of the picture and exaggerates the

\footnotetext{
${ }^{29}$ ICRC 2012; Slim and Bonwick 2005, p. 86.

${ }^{30}$ Lischer 2003, p. 102.

${ }^{31}$ Knudsen 2008.

${ }^{32}$ Giumelli 2015; Radtke and Jo 2018.

${ }^{33}$ Biersteker and Hudáková 2015, p. 7.
} 
Table 17.3 Mechanisms and means for influencing actors undermining deterrence in peace operations

\begin{tabular}{|c|c|}
\hline $\begin{array}{l}\text { Persuasion: information, } \\
\text { education and training }\end{array}$ & $\begin{array}{l}\text { General: } \\
\text { - IHL and human rights training, education and information } \\
\text { campaigns } \\
\text { - Campaigns aimed at banning weapons systems, stopping the } \\
\text { proliferation of small and light arms, the use of child soldiers } \\
\text { and so on } \\
\text { Immediate: } \\
\text { - Explaining combatant objectives are best achieved by means } \\
\text { of negotiation and will be undermined by use of force } \\
\text { - Informing combatants about their IHL obligations and } \\
\text { humanitarian principles in order to gain access to civilians in } \\
\text { need } \\
\text { - Providing information about atrocities and violations to } \\
\text { advocacy groups, journalists, governmental organisations } \\
\text { and governments } \\
\text { - Appeals to all actors undermining deterrence in a given } \\
\text { conflict to take steps to stop the use of force }\end{array}$ \\
\hline $\begin{array}{l}\text { Inducement: promises and } \\
\text { rewards }\end{array}$ & $\begin{array}{l}\text { - Legitimacy derived from cooperating with internationally } \\
\text { recognized organisations } \\
\text { - Humanitarian assistance to civilians enabling governments } \\
\text { and armed groups to divert resources to military capacities } \\
\text { or gain support from the local population } \\
\text { - Payment for accommodation, services and local staff } \\
\text { benefiting the local economy and thereby governments and } \\
\text { armed groups } \\
\text { - Direct payment to combatants for protection and } \\
\text { humanitarian access } \\
\text { - (Promise of) silence concerning human suffering and } \\
\text { violence in exchange for compliance }\end{array}$ \\
\hline $\begin{array}{l}\text { Coercion: threats and } \\
\text { punishment }\end{array}$ & $\begin{array}{l}\text { - (Threat to engage in) naming and shaming of all types of } \\
\text { actors contributing to undermine deterrence in order to } \\
\text { mobilize local, regional and global pressure on them to stop } \\
\text { - (Threat to issue) calls for diplomatic, economic, or military } \\
\text { measures against all types of actors contributing to } \\
\text { deterrence failure at the local, regional and global levels } \\
\text { - (Threat to) suspend or terminate humanitarian operations } \\
\text { and peace negotiations } \\
\text { - (Threat to) punish aggressors/deny them their objectives } \\
\text { politically, economically and militarily } \\
\text { - (Threat to) use force to enforce compliance with } \\
\text { international demands at tactical or strategic levels }\end{array}$ \\
\hline
\end{tabular}

(Source The author)

contribution made by battlefield deterrence to overall success. The peace operations literature assumes wrongly that effective deterrence hinges on the deployment of a peace force capable of threatening and using force against the combatants in a way that will make aggression too costly. Yet many peace forces have contributed to successful deterrence without meeting these requirements, because their 
deployment was supported by the use of persuasion, inducements and other forms of coercion such as threats or use of diplomatic and economic sanctions that made the costs of aggression too high for the combatants, their allies and supporters and the costs of inaction too high for the bystanders. The UN operation in Sierra Leone (UNAMSIL) illustrates the limits of battlefield deterrence and highlights the advantages of adopting the more comprehensive understanding of deterrence proposed in this chapter.

\subsection{Reinterpreting UNAMSIL}

UNAMSIL has been chosen because it constitutes a paradigmatic case for the robust peacekeeping school. Its proponents use it to argue that combat capable peace forces are a sine qua non for deterrence and mission success. While it is true that UNAMSIL's eventual success in part can be attributed to the deployment of combat capable forces and effective use of limited force, it is equally clear that it took far more than credible threats and use of force to turn the operation around (see Table 17.4).

UNAMSIL (1999-2005) had a chapter VII mandate authorizing the use of force beyond self-defence to protect civilians and implement a peace agreement between the government of Sierra Leone and the rebel movement Revolutionary United Front (RUF). The mission got off to a bad start when RUF reneged on its commitment to disarm and took over 500 UN soldiers hostage in May 2000. Fearing the collapse of UNAMSIL, UN Secretary-General (UNSG) Kofi Annan appealed to the three bystanders with the capacity to prevent it from happening: France, the United Kingdom (UK) and the United States. The UK responded positively to the appeal undertaking a hasty deployment of 700 paratroopers to evacuate Western citizens, stabilize the situation and prevent the collapse of the UN mission. The UK subsequently beefed up an existing Security Sector Reform (SSR) program enabling the Sierra Leonean army and police to take more effective action against RUF. The UK also took the lead with respect to mobilize support for UNAMSIL in the UN Security Council. It penned subsequent UN resolutions strengthening the UNAMSIL mandate and increasing the size of the force from 11,000 to 17,000 personnel. The United States supported the UK efforts and stepped up its military support for African countries providing troops for UNAMSIL. The UK also penned UN resolutions targeting the principal combatant allies and supporters that enabled RUF to continue its aggression. These resolutions imposed sanctions on Libya to deny it the ability to provide material support to RUF and named and shamed Burkina Faso into ceasing its assisting weapon sales to RUF. These actions were in part prompted by a global NGO advocacy campaign against blood diamonds, which pressured bystanders to take action to make it harder for RUF to finance its military campaign with the sale of diamonds. These efforts enjoyed strong regional support as the Economic Community of West African States (ECOWAS) led by Nigeria pressured RUF and Liberia to accept the Abuja Cease Fire Agreements I (2000) and 
Table 17.4 Influencing the coalition of actors undermining deterrence in Sierra Leone 2000-2002

\begin{tabular}{|c|c|c|c|c|}
\hline & Persuasion & Inducements & Coercion & Outcome \\
\hline $\begin{array}{l}\text { Combatants } \\
\text { - Armed Forces } \\
\text { Revolutionary } \\
\text { Council (AFC) } \\
\text {-Kamajors } \\
\text {-Revolutionary } \\
\text { United Front } \\
\text { (RUF) } \\
\text { - Sierra } \\
\text { Leone's Army } \\
\text { (SLA) } \\
\text { - West Side } \\
\text { Boys (WSB) }\end{array}$ & $\begin{array}{l}\text { UK and UN media } \\
\text { campaigns } \\
\text { highlighting benefits } \\
\text { of peace process and } \\
\text { costs of resistance, } \\
\text { - UNAMSIL } \\
\text { outreach program } \\
\text { - ECOWAS } \\
\text { brokered Abuja } \\
\text { Cease Fire } \\
\text { Agreements I (2000) } \\
\text { and II (2001) } \\
\text { - Training of SLA } \\
\text { military and the } \\
\text { police force }\end{array}$ & $\begin{array}{l}\text { - Amnesty for } \\
\text { combatants } \\
\text { - Cash } \\
\text { payments and } \\
\text { skills training } \\
\text { for } \\
\text { ex-combatants } \\
\text { - Government } \\
\text { release of RUF } \\
\text { prisoners as } \\
\text { reward for } \\
\text { compliance } \\
\text { (2001) } \\
\text { - Rebel } \\
\text { integration into } \\
\text { national army } \\
\text { - Increased pay } \\
\text { for soldiers and } \\
\text { police } \\
\text { - Quick impact } \\
\text { projects to win } \\
\text { popular } \\
\text { support } \\
\text { - Truth and } \\
\text { Reconciliation } \\
\text { Commission } \\
\text { (2002) }\end{array}$ & $\begin{array}{l}\text { - UK use of force } \\
\text { destroys WSB (2000) } \\
\text { - UK over horizon } \\
\text { force punishing } \\
\text { non-compliance } \\
\text { - UK supported SLA } \\
\text { operations against RUF } \\
\text { (2000) } \\
\text { - Guinea defeat of RUF } \\
\text { offensive (2001) } \\
\text { - More assertive } \\
\text { UNAMSIL (2001) } \\
\text { - Economic sanctions } \\
\text { imposed on RUF } \\
\text { (2001) } \\
\text { - UN War crimes } \\
\text { tribunal (2002) }\end{array}$ & $\begin{array}{l}\text { - Successful } \\
\text { disarmament (2002) } \\
\text { - Election result } \\
\text { respected by } \\
\text { combatants (2002) }\end{array}$ \\
\hline $\begin{array}{l}\text { Combatant } \\
\text { allies } \\
\text { - Liberia } \\
\text { provided } \\
\text { weapons and } \\
\text { training to RUF } \\
\text { and bought its } \\
\text { diamonds }\end{array}$ & & & $\begin{array}{l}\text { - NGO and UN reports } \\
\text { naming and shaming } \\
\text { Liberia for supporting } \\
\text { RUF (2000, 2001) } \\
\text { - UN arms embargo, } \\
\text { ban on diamond } \\
\text { exports travel ban } \\
\text { imposed on Liberia } \\
(2001)\end{array}$ & $\begin{array}{l}\text { - Support for RUF } \\
\text { significantly } \\
\text { reduced }\end{array}$ \\
\hline $\begin{array}{l}\text { Combatant } \\
\text { Supporters } \\
\text { Burkina Faso } \\
\text { helped RUF to } \\
\text { sell diamonds } \\
\text { and buy arms }\end{array}$ & $\begin{array}{l}\text { - NGO advocacy } \\
\text { campaign against } \\
\text { blood diamonds }\end{array}$ & & $\begin{array}{l}\text { NGO, UK, US and UN } \\
\text { naming and shaming } \\
\text { Burkina Faso for } \\
\text { assisting RUF (2001) }\end{array}$ & $\begin{array}{l}\text { Burkina Faso ceased } \\
\text { its support for RUF }\end{array}$ \\
\hline $\begin{array}{l}\text { Bystanders } \\
\text { - United } \\
\text { Kingdom } \\
\text { - United States } \\
\text { - France }\end{array}$ & $\begin{array}{l}\text { UNSG Annan } \\
\text { appeal to the three } \\
\text { bystanders to } \\
\text { intervene to prevent } \\
\text { UNAMSIL collapse } \\
\text { (2000) } \\
\text { - NGO advocacy } \\
\text { campaign against } \\
\text { trade with blood } \\
\text { diamonds from } \\
\text { Sierra Leone }\end{array}$ & & $\begin{array}{l}\text { NGO advocacy } \\
\text { campaign naming and } \\
\text { shaming governments } \\
\text { and firms facilitating } \\
\text { trade with blood } \\
\text { diamonds from Sierra } \\
\text { Leone } \\
\text { - Consumer boycotts } \\
\text { against blood } \\
\text { diamonds }\end{array}$ & $\begin{array}{l}\text { - UK military } \\
\text { intervention, and } \\
\text { leadership in UNSC } \\
(2000-2002) \\
\text { - US support of UK } \\
\text { - US training of } \\
\text { African UNAMSIL } \\
\text { contingents (2000) }\end{array}$ \\
\hline
\end{tabular}

(Source Berman and Labonte 2006; Rashid 2016; Ucko 2016) 
II (2001). In addition, Guinea successfully defeated a 2001 RUF offensive weakening its military capacity considerably.

In sum, it took the efforts of a deterring coalition made up of a united Security Council led by the UK, a global NGO advocacy campaign against blood diamonds, strong regional diplomatic and military support, strengthened government security forces, active military support from the UK and a reorganized and strengthened UNAMSIL peace force to produce the disarmament of RUF and the national election that ended the civil war in Sierra Leone in 2002. As is clear from Table 17.4, the deterring actors relied on a combination of diplomacy, inducement and coercion to achieve this result. The significant strengthening of the UN force in 2000-2001 may well have been a necessary condition for the successful outcome of the UNAMSIL operation. But it was by no means sufficient, and it would not have succeeded in the absence of the other factors supporting its efforts at the local, regional and global levels.

\subsection{Conclusion}

The peace operations literature regards the deployment of a peace force capable of threatening and using force to punish aggressors or deny them their objectives as the sine qua non to deter violence and protect civilians. It ignores that deterrence needs to be established and maintained at other levels as well, and it cannot explain why unarmed military observers and peacekeeping forces incapable of threatening and using force have often contributed to deterrence and mission success. This chapter has developed a new analytical framework that solves this puzzle. To be successful actors deploying peace forces must not only deter combatants from using force. They must also deter the allies and supporters that enable combatants to use force, and they must influence bystanders with a capacity to make a difference to take action against them. To succeed deterring actors cannot rely solely on threats and use of force. They must supplement their use of coercion with persuasion and inducement and devise and implement influence strategies that draw on all three components. At present theorists and practitioners ask the following question when contemplating the deployment of a peace operation: how much military capacity will it take to deter or compel the combatants from using force at the tactical or strategic level? Instead, they need to adopt a wider perspective and ask the following questions:

(1) Who are the principal combatants, how much military capability do they have, and how can they be influenced to refrain from using it by means of persuasion, inducement and coercion?

(2) Who are the principal combatant allies, how do they support the combatants and how can their support be stopped by means of persuasion, inducement and coercion? 
(3) Who are the principal combatant supporters, how do they support the combatants and how can their support be stopped by means of persuasion, inducement and coercion?

(4) Who are the principal bystanders with a capacity to influence the combatants, their allies and supporters, and how can they be influenced to act by means of persuasion, inducement and coercion?

Deterring actors contemplating the deployment of peace forces to deter the use of force must ask and revisit these four questions repeatedly as the peace operation evolves. The coalition of actors undermining deterrence may change in the course of the operation, and so will the (lack of) opportunities to influence each of its members. The answers provided to these questions are crucial for devising effective influence strategies. An influence strategy must be tailored to each actor contributing to undermine deterrence, and each strategy should combine persuasion, inducement and coercion for maximum impact.

\section{References}

Abild E (2009) Creating humanitarian space: a case study of Somalia. UNHCR Research Paper 184.

Berdal M (2019) What Are the Limits to the Use of Force in UN Peacekeeping? In: De Coning C, Peter M (eds) United Nations Peace Operations in a Changing Global Order. Palgrave Macmillan, Cham, 113-132. https://link.springer.com/content/pdf/10.1007\%2F978-3-31999106-1_6.pdf. Accessed 3 August 2020

Berman E G, Labonte M T (2006) Sierra Leone. In: Durch W J (ed) Twenty-First-Century Peace Operations. United States Institute of Peace, Washington DC, 141-227

Biersteker T, Hudáková Z (2015) UN sanctions and peace negotiations: possibilities for complementarity. Oslo Forum Papers 4

Cruz C A S, Philips W R, Cusimano S (2017) Improving Security of United Nations Peacekeepers. United Nations, New York

Findlay T (2003) The use of force in UN peace operations. Oxford University Press, Oxford

Freedman L (2013) Disarmament and Other Nuclear Norms. Washington Quarterly 36.2:92-108

George A L (2003) The Need for Influence Theory and Actor-Specific Behavioral Models of Adversaries. Comparative Strategy 22.5:463-487, https://doi.org/10.1080/ 01495930390256527 Accessed 3 August 2020

George A L, Smoke R (1974) Deterrence in American Foreign Policy. Columbia University Press, New York

Giumelli F (2015) Understanding United Nations targeted sanctions: an empirical analysis. International Affairs 91.6:1351-1368

Grace R (2015) Frontline Negotiations with Non-State Armed Groups. Harvard Humanitarian Initiative's Advanced Training Program on Humanitarian Action, Harvard

Howard L M (2019) Power in Peacekeeping. Cambridge University Press, Cambridge

Humanitarian Negotiations Information Portal, http://www.humanitariannegotiations.org/resourcedatabase/. Accessed 3 August 2020

ICRC (2012) Enhancing protection https://www.icrc.org/eng/assets/files/other/icrc-002-0956.pdf Accessed 3 August 2020

ICRC (2015) Safer Access for all National Societies Increasing acceptance, security and access to people and communities in need http://saferaccess.icrc.org/. Accessed 15 January 2020 
Jackson A (2012) Talking to the Other Side: Humanitarian Engagement with Armed Non-State Actors. HPG Policy Brief 47

Jackson A, Aynte A (2013) Talking to the other side: Humanitarian negotiations with Al-Shabaab in Somalia. HPG Working Paper December

Jakobsen P V (1998) Western Use of Coercive Diplomacy: A Challenge for Theory and Practice. Palgrave Macmillan/Houndmills, Basingstoke, Hampshire

Jakobsen P V (2000a) The Emerging Consensus on Grey Area Peace Operations Doctrine: Will It Last and Enhance Operational Effectiveness? International Peacekeeping 7.3:36-56 https://doi. org/10.1080/13533310008413848. Accessed 3 August 2020

Jakobsen P V (2000b) Reinterpreting western use of coercion in Bosnia-Herzegovina: Assurances and carrots were crucial. Journal of Strategic Studies 23.2:1-22. https://doi.org/10.1080/ 01402390008437788. Accessed 3 August 2020

James A (1990) Peacekeeping in International Politics. St. Martin's Press, New York

Jervis R (1979) Deterrence Theory Revisited. World Politics 31.2:289-324. https://doi.org/10. 2307/2009945. Accessed 3 August 2020

Karlsrud J (2015) The UN at war: examining the consequences of peace enforcement mandates for the UN peacekeeping operations in the CAR, the DRC and Mali. Third World Quarterly 36.1:40-54. https://doi.org/10.1080/01436597.2015.976016. Accessed 3 August 2020

Kellenberger J (2004) Speaking Out or Remaining Silent in Humanitarian Work. International Review of the Red Cross 86.855:593-609

Knopf J W (2010) The Fourth Wave in Deterrence Research. Contemporary Security Policy 31.1:1-33. https://doi.org/10.1080/13523261003640819. Accessed 3 August 2020

Knudsen R A (2008) The Comprehensive UN Sanctions against the Federal Republic of Yugoslavia - Aims, Impact and Legacy. Kolofon Forlag, Oslo

Lischer S K (2003) Collateral Damage: Humanitarian Assistance as a Cause of Conflict. International Security 28.1:79-109. https://doi.org/10.1162/016228803322427983. Accessed 3 August 2020

Loeb J (2013) Talking to the other side Humanitarian engagement with armed non-state actors in Darfur, Sudan, 2003-2012. HPG Working Paper August

Lupovici A (2010) The Emerging Fourth Wave of Deterrence Theory-Toward a New Research Agenda. International Studies Quarterly 54.3:705-732. https://doi.org/10.1111/j.1468-2478. 2010.00606.x. Accessed 3 August 2020

Lynch C (2014a) Now We Will Kill You. Foreign Policy 8 April 2014. https://foreignpolicy.com/ 2014/04/08/now-we-will-kill-you/. Accessed 3 August 2020

Lynch C (2014b) A Mission That Was Set Up to Fail. Foreign Policy 8 April 2014. https:// foreignpolicy.com/2014/04/08/a-mission-that-was-set-up-to-fail/. Accessed 3 August 2020

Magone C, Neuman N, Weissman F (2011) Humanitarian Negotiations Revealed. The MSF Experience. Hurst \& Company, London

McHugh G, Bessler M (2006) Humanitarian Negotiations with Armed Groups A Manual for Practitioners. United Nations, Ocha

Nsia-Pepra K (2017) Moral Obligation: Un Missions Should Not Abandon Vulnerable Civilians In Critical Times 25 August 2017. https://peaceoperationsreview.org/thematic-essays/moralobligation-un-missions-should-not-abandon-vulnerable-civilians-in-critical-times/. Accessed 3 August 2020

Nye Jr S (2016/17) Deterrence and Dissuasion in Cyberspace. International Security 41.3:44-71. https://www.mitpressjournals.org/doi/pdf/10.1162/ISEC_a_00266. Accessed 3 August 2020

Radtke M, Jo H (2018) Fighting the Hydra: United Nations sanctions and rebel groups. Journal of Peace Research 55.6:759-773

Rashid I (2016) Sierra Leone: The Revolutionary United Front. In: Hughes M, Miklaucic M (eds) Impunity: Countering Illicit Power in War and Transition. National Defense University, Washington DC, 190-216

Schirch L (2006) Civilian Peacekeeping. Life \& Peace Institute, Östervåla

Shinn D H (2009) China and the Conflict in Darfur. The Brown Journal of World Affairs 16.1:85-100. https://www.jstor.org/stable/24590742. Accessed 3 August 2020 
Slim H, Bonwick A (2005) Protection: An ALNAP Guide for Humanitarian Agencies. Overseas Development Institute, London

Snyder G H (1961) Deterrence and Defense: Toward a Theory of National Security. Princeton University Press, Princeton

Stein J G (1991) Deterrence and reassurance. In: Tetlock P E, Husbands J L, Jervis R, Stern P C, Tilly C (eds) Behaviour, society and nuclear war. Oxford University Press, New York, 9-72

Tannenwald N (2007) The Nuclear Taboo: The United States and the Non-Use of Nuclear Weapons since 1945. Cambridge University Press, Cambridge

Ucko D H (2016) Can Limited Intervention Work? Lessons from Britain's Success Story in Sierra Leone. Journal of Strategic Studies 39.5-6:847-877. https://doi.org/10.1080/01402390.2015. 1110695. Accessed 3 August 2020

United States Department of Defense (2006) Deterrence Operations Joint Operating Concept. United States Department of Defense, Washington. https://www.jcs.mil/Portals/36/Documents/ Doctrine/concepts/joc_deterrence.pdf?ver=2017-12-28-162015-337. Accessed 3 August 2020

Wilner A (2011) Deterring the Undeterrable: Coercion, Denial, and Delegitimization in Counterterrorism. Journal of Strategic Studies 34.1:3-37. http://dx.doi.org/10.1080/ 01402390.2011.541760. Accessed 3 August 2020

Peter Viggo Jakobsen (Ph.D.) is Associate Professor at the Institute for Strategy at the Royal Danish Defence College, and Professor (part time) at the Center for War Studies, University of Southern Denmark. He has written extensively on coercion, coercive diplomacy, deterrence, peace operations and the use of force.

Open Access This chapter is licensed under the terms of the Creative Commons Attribution 4.0 International License (http://creativecommons.org/licenses/by/4.0/), which permits use, sharing, adaptation, distribution and reproduction in any medium or format, as long as you give appropriate credit to the original author(s) and the source, provide a link to the Creative Commons license and indicate if changes were made.

The images or other third party material in this chapter are included in the chapter's Creative Commons license, unless indicated otherwise in a credit line to the material. If material is not included in the chapter's Creative Commons license and your intended use is not permitted by statutory regulation or exceeds the permitted use, you will need to obtain permission directly from the copyright holder. 